\section{SOI: 1.1/TAS DOI: 10.15863/TAS International Scientific Journal Theoretical \& Applied Science}

p-ISSN: 2308-4944 (print) e-ISSN: 2409-0085 (online)

Year: 2017 Issue: 02 Volume: 46

Published: $28.02 .2017 \quad$ http://T-Science.org
Kristina Viktorovna Boychenko

Master of science in Architecture, Department of Architecture and Engineering Polytechnic University of Milan, Milan, Italy tina.architect@gmail.com ORCID 0000-0002-9680-9618

SECTION 8. Architecture and Construction

\title{
MASS CUSTOMIZATION IN ARCHITECTURE
}

Abstract: The article considers mass customization as a new approach to manufacturing in the field of architecture and construction, significantly different from mass production approach. New technical and technological capabilities allow to overcome the constraints of mass production in favour of each structural element individualization, providing buildings with new characteristics.

Key words: interactive architecture, smart environment, behavior, senses, communication, society.

Language: English

Citation: Boychenko KV (2017) MASS CUSTOMIZATION IN ARCHITECTURE. ISJ Theoretical \& Applied Science, 02 (46): 49-51.

Soi: http://s-o-i.org/1.1/TAS-02-46-10 Doi: crossef https://dx.doi.org/10.15863/TAS.2017.02.46.10

\section{UDC 21474}

\section{Introduction}

At the beginning of the century industrialized economies were based on mass production, mass distribution, mass marketing and mass media. However, the full range of improvements in information and technology makes it more and more possible to shift in the direction of mass customization. It allows to give a quick response on consumer demand by creating customized products at prices of mass production.

Challenged by the recent economic crisis, the building and construction industry is currently seeking new orientation and strategies. In the world of technological progress mass customization is a key strategy in helping to meet this challenge. The term mass customisation denotes an offering that meets the demands of each individual customer, whilst still being produced with mass production efficiency. Today mass customisation is emerging from a pilot stage into a scalable and sustainable strategy.[1]

Computerization strongly influenced all aspects of the project. Not only design processes and economy of design transformed, it has converted nature of the products that can be created. CAD system allows a group of designers and other professionals to collaborate in new ways to visualize and try out different options. Software design has moved from being merely a tool to becoming an intellectual environment that can inform and guide the design process.[2]

\section{Mass customization vs. Mass Production}

Construction as a public field is based on the industrial mass production of building components. Elements produced as a versatile material, that will be customized later on the other phase of the product life. Intermediate products are produced in a limited range of sizes and measurements and then stored and cataloged, expecting that they will be used by the next group, eventually ending their way during assembly at the factory or installed as part of the structure. Mass-produced elements are categorized and are specialized in categorized in different classes: doors, beams, windows, columns, tiles, bricks, rods, wires, pipes, etc. Production following the principle of mass customization works in a completely different way. There are no catalogs, products are produced from raw materials (which in most cases are mass produces) for a particular purpose, becoming a unique part in a unique structure in a particular building.

The architecture based on a new paradigm of mass customization, will be significantly different from the conventional building design, which we have seen so far. Completely new tools developed to create the diversity and complexity are the basis for the work of visual and structural richness and diversity. All this is based on simple rules applied in the treatment of behavioral patterns to produce relationships between all the building components. The driving force for the organization of behavior of the control points of geometry arises from external 
and internal forces communicating with the development of three-dimensional model. [6]

There is significant difference between mass production and mass customization from busimess point of view.

"The traditional mass production company is bureaucratic and hierarchical. Under close supervision, workers repeat narrowly defined, repetitious tasks. Result: low-cost, standard goods and services." [4]

Typical results in architecture: process, techniques and designs that are homogeneous, rigid, fixes, authoritarian, hierarchical, pre-determined, formulaic, etc. [9]

"Mass customization calls for flexibility and quick responsiveness. In an ever-changing environment, people, processes, units, and technology reconfigure to give customers exactly what they want. Managers coordinate independent, capable individuals, and an efficient linkage system is crucial. Result: low-cost, high-quality, customized goods and services". [5]

Typical results in architecture: processes, techniques and designs that are heterogeneous, flexible, adaptable, collaborative, non-hierarchical, parameter based, etc. [9]

\section{Customization typology}

There are three ways to customize products: modular, adjacent, and dimensional customization.

Modular customization: modules are the building blocks. Usually modules are literally the standard blocks that can customize the product for their assembly into different combinations.

Adjacent customization: adjustments are the reversible way to customize the product. There exist both mechanical and electrical adjustment. Adjustments can be done indefinitely. Separate adjustment or configuration provide a limited selection. These adjustments and configuration can be set in production, vendor or customer.

Dimensional customization: Dimensional customization uses irrevocable trimming to fit the size, merging or device. Dimension customization can be without limitation or have a limited set of choices. Dimensionally customized parts can be made automatically using the equipment with numerical control using the commands, generated by the data with parametric software. [6]

The scheme used to produce a mass customization product, is when the designer provides a specific set of configurations. Another scheme is co-designing. The co-designing also has option of configuring the product. At the same time consumers are also allowed to interact with the product more close.

At the core of mass customization lie the changes of the current relationship between production and consumption. The nature of communication between producers and consumers varies from one-way communication to an interactive dialogue.

\section{Importance of mass customization}

The task of the design also changes. Clearly, the customization should be embedded directly in products. The task of the designer shifts from the design of definitely immutable products to the design of platforms for design and architecture and set of design rules that define the range of product solutions. Similarly, the new product design process will also include development of design tools and interface for consumers as co-designers, able to customize or to decide what is possible to model as the actual product.

Design moves out of the pre-production process and becomes part of a full production process.[2]

People are connected to the machine-machine communication through mediation schemes and through a variety of input devices. This adjustment process is referred to a method, based on the mass production, a so-called face to face production. Now everything can be different in absolute size and position, not because of human mistakes, but thanks to the computational processing of diversity.

Considering the world from the paradigm of mass customization, it includes all possible products on the assembly line of mass production. By setting all the parameters to the same value, we can easily get down from the level of mass customization to the level of mass production. Vice-versa is impossible. Mass customization does include mass production, while the mass production definitely does not include mass customization.

The ultimate goal of Swarm architecture is to keep its' new structures up-to dated in real time. The objective of information architecture projects is to support the vitality of the process and apply the values to the behavior in real-time, to understand how can the designers create a tunnel for a continuous flow of data within the built structure, where the content is constantly changing in real time? To facilitate this fundamentally new view of the world, we have to look at the building as if they are appliances that can be run in real-time. These dynamic buildings by Oosterhuis can be considered as existing processes that continuously inform users and are informed themselves continuously during other active processes. They are the active nodes in a complex adaptive operating network. [7, 8]

\section{Conclusion}

A true understanding of peer-to-peer network of machines communicating with machines, linking the flows of information leads to a complete new understanding of the architect / designer activity. Kas Oosterhuis encourages to improve one's knowledge and start to design rules for the behavior of all the possible checkpoints and restrictions on their 


\begin{tabular}{l|lrl|l|ll} 
& ISRA (India) & $=\mathbf{1 . 3 4 4}$ & SIS (USA) & $=\mathbf{0 . 9 1 2}$ & ICV (Poland) & $=\mathbf{6 . 6 3 0}$ \\
Impact Factor: & ISI (Dubai, UAE) $=\mathbf{0 . 8 2 9}$ & PUHL (Russia) $=\mathbf{0 . 2 3 4}$ & PIF (India) & $=\mathbf{1 . 9 4 0}$ \\
& GIF (Australia) & $\mathbf{0 . 5 6 4}$ & ESJI (KZ) & $=1.042$ & IBI (India) & $=\mathbf{4 . 2 6 0}$
\end{tabular}

behavior, rather than thinking about the abundance and complexity as exceptions from the standards. All the possible positions of the control points are no longer seen as an unusual condition, but as implicit possible states in accumulating relationships between the points. The point cloud can be seen as a quantum system in geometry. There are no exceptions to this standard, rules for calculating the control points are non-standard, the exception has become the rule. Strengthening of such a position can be understood as the shift from the world of plans and crosssections towards a truly three-dimensional space.
Now move out of mass production and mass copying realm into the field of mass customization and complexity, possible by means of programming. [6]

The importance of mass customization in fast developing society with new fascinating technologies is hard to overestimate from different points of view. Mass customization has tremendous potentials and possibilities in critically transforming architectural practices, pedagogies and production [9]. There are no doubts it will find more and more implementations in modern Architecture. [10]

\section{References:}

1. Poorang AE, Piroozfar, Frank T. Piller (2013) Mass Customization and Personalisation in Architecture and Construction // Routledge July 3, 2013.

2. Tim Crayton (2001) The design implication to Mass Customization // Design Intelligence, 2001 . №5

3. Kas Oosterhuis (2004) Towards a New Kind of Building: A Designers Guide for Nonstandard Architecture // TU Delft, 2004.

4. James H. Gilmore, Joseph Pine II (2000) Markets of One: Creating Customer-Unique Value through Mass Customization // Boston: Harvard Business Review, ed. 2000.

5. Demetrios Eames (2002) An Eames Primer // Universe Books 2002.
6. David M. Anderson (2004) Mass Customization, the Proactive Management of Variety // PC AI Magazine, 2004.

7. Kas Oosterhuis (2006) Swarm Architecture II // TU Delft, 2006.

8. Kristina Boychenko (2017) Sences and Behavior of Interactive Environment // Вестник Науки и Образования 2017 №2 (26) February.

9. Wanda Dye (2004) Mass Customization in Architecture: Heterogenity in the making // 92nd ACSA Annual Meeting, Miami FL March 18-21, 2004 №215.

10. Kristina Boychenko (2017) Interactive Architecture: development and implementation into the built environment // European Journal of Technology and Design 2017 Vol. (15) March 